\title{
Exploration of Marine Tourism in Watulimo, Trenggalek Regency: Challenges, Potentials, and Development Strategies
}

\author{
Rita Parmawati ${ }^{*}$, Amin Setyo Leksono, Bagyo Yanuwiadi, Agung Sih Kurnianto \\ Graduate School of Environmental Sciences, University of Brawijaya, Malang, Indonesia
}

\begin{abstract}
Watulimo District, Trenggalek Regency is one of the area in East Java Province that has an abundant marine potential. However, this huge potential has not been optimally developed in a form of marine tourism. This study aims to determine internal and external factors that influence the development of marine tourism in Watulimo Subdistrict, Trenggalek, and develop a strategy of marine tourism development in a sustainable manner. This study was conducted on 4 beaches in Watulimo Subdistrict, Trenggalek Regency: Prigi, Karanggongso, Cengkrong, and Damas. Interviews were conducted by using semi-structured technique. Secondary data is obtained from government policy documents relating to tourism; tourism infrastructure facilities in the research location; data of tourist visits; geography and demographics; socio-cultural and economic data. Most respondents believe that promotion (0.083) and tourist information center (0.075) indicator are considered very important. Advances in information technology have the highest weight (0.097), where respondents can know about the state of the marine tourism area based on information and reviews. The results show the number of scores obtained from the weighting and external factor rating of 2.656 (good value range), which illustrates that the marine tourism area in Watulimo has an opportunity in its development. Cooperation with travel agents, hotels, restaurants, and tourist information centers for Trenggalek District can be incorporated into their brochures to increase traffic.
\end{abstract}

Keywords: development, information, promotion, tourism, Watulimo.

\section{INTRODUCTION}

Watulimo District, Trenggalek Regency is one of the area in East Java Province that has an abundant marine potential. There are several beach area such as Prigi $(2.5 \mathrm{~km})$, Karanggongso $(1 \mathrm{~km})$, and Damas $(5 \mathrm{~km})$ which are visited by domestic tourist. The development of marinebased tourism in Trenggalek Regency is important to enhance the local economic development and crucial in poverty reduction strategy.

One of the potential sites for tourism development, but less developed, is Cengkrong Beach. Naturally, Cengkrong Beach has a natural mangrove forest that are important to support coastal biodiversity $[1,2,3]$. However, this huge potential has not been optimally developed in a form of marine tourism. The activities in each tourist attraction still occur independently and not connected. The facts stated that tourist visit focused on a single tourist attraction, which is Karanggongso Beach, and there is a stagnant or decreased visits on other beaches. It is recorded that Kranggongso Beach visitors reaches up to 337,180 in 2014 . This is very much different

\footnotetext{
${ }^{*}$ Correspondence address:

Rita Parmawati

Email : rita_parmawati@ub.ac.id

Address: Graduate School, University if Brawijaya, Mayjen Haryono no.169, 65145Malang.
}

compared to other beaches, namely Prigi $(82,211)$ and Damas $(29,187)[4]$.

Marine tourism is one type of tourism that has a major contribution to the economy $[5,6]$. The contribution of marine tourism to national development is the provision of employment and other economic activities (multiplier effect) and foreign exchange earnings $[7,8]$ by a region, not hence become a competitive advantage. Thus, it is necessary to have a well-planned and longterm strategy for marine tourism to truly be one of the economically sustainable areas/ecosystems [2]. In addition, a direction is needed as an effort to develop the tourism sector in Watulimo District by combining and integrating a number of marine tourism potentials that exist in one area to increase tourist visits. This study aims to determine internal and external factors that influence the development of marine tourism in Watulimo Subdistrict, Trenggalek, and develop a strategy of marine tourism development in a sustainable manner.

\section{MATERIALS AND METHOD \\ Study sites}

This study was conducted on four beaches in Watulimo Subdistrict, Trenggalek Regency: Prigi Beach, Karanggongso, Cengkrong, and Damas (Fig. 1). Prigi is a beach with a coastal length of $2.5 \mathrm{~km}$ and has a soft and white sand beach. This beach has the most complete modern facilities: 
parking area, camping ground, sport center, hotels, and restaurant. There is a fish port in the west. Larung Semboyo, a maritime festival that attracts many tourist, was done every year in this area. Karanggongso is a beach in a sheltered bay, so it has a calmer waves than Prigi. This beach has no major management, either by government or community-based. The tourists visit number was very little. The micro climate on the beach is quite cool, because of the abundance of coconut trees and Ketapang (Terminalia catappa) growing on this sandy beach. Other objects other than the beach are Pearl Rocks and Red Cave. Both are often used as a photo object by tourists.

Cengkrong has another value, namely the existence of mangrove forest and its management that involve the local community as ecotourism [3]. Last, Damas beach is located at 5 $\mathrm{km}$ southwest of Prigi. Although it is not as white as Prigi's, Damas sand is quite soft. The beach is also shady because of the abundance of coconut and Ketapang trees. Its location at bay makes the currents and waves are very calm, allowing some tourist activities, such as surfing, fishing, and swimming.

\section{Data Collection}

Informants were determined purposively through several criteria, i.e. has a knowledge on the problems identified, accepted by various society element, and has a tourism knowledge. The informants were: Departement of Youth and Sports $(n=3)$. District Secretary $(n=1)$, Village Head $(n=1)$, Village Secretary $(n=1)$, Chairman of Tourism Awareness Group (Kelompok Sadar
Wisata) $(n=1)$, Community Leader $(n=2)$, Tourism Industry Entrepreneurs $(n=7)$, Academics $(n=3)$, and Tourist $(n=10)$. Interviews were conducted at oncewith semi-structured method, as primary data. Interview questions include:

a) Development: number of tourist visits, assets (tourism facilities), and profit

b) Stability: improvement and development

c) Survival: negative tendencies/weaknesses, coping strategies weakness,

d) Diversification: diversity of attractions/ products.

Observations were made on the physical condition and activity at the site, then documented. Secondary data is obtained from government policy data related to tourism, tourism infrastructure facilities in the research location, data of tourist visits, geography and demographics, as well as socio-cultural and economic data.

\section{Data Analysis}

The data obtained are processed by classification according to the order of the problems and the classification of internal and external factors. After the classification, we do strategy development using SWOT analysis. All elements in the SWOT will be compiledthrough the respondent's answer to the question posed. SWOT analysis is used to identify and formulate a strategy. The SWOT analysis is based on logic to maximize Strength and Opportunity, while simultaneously minimizing Weakness and Threats.

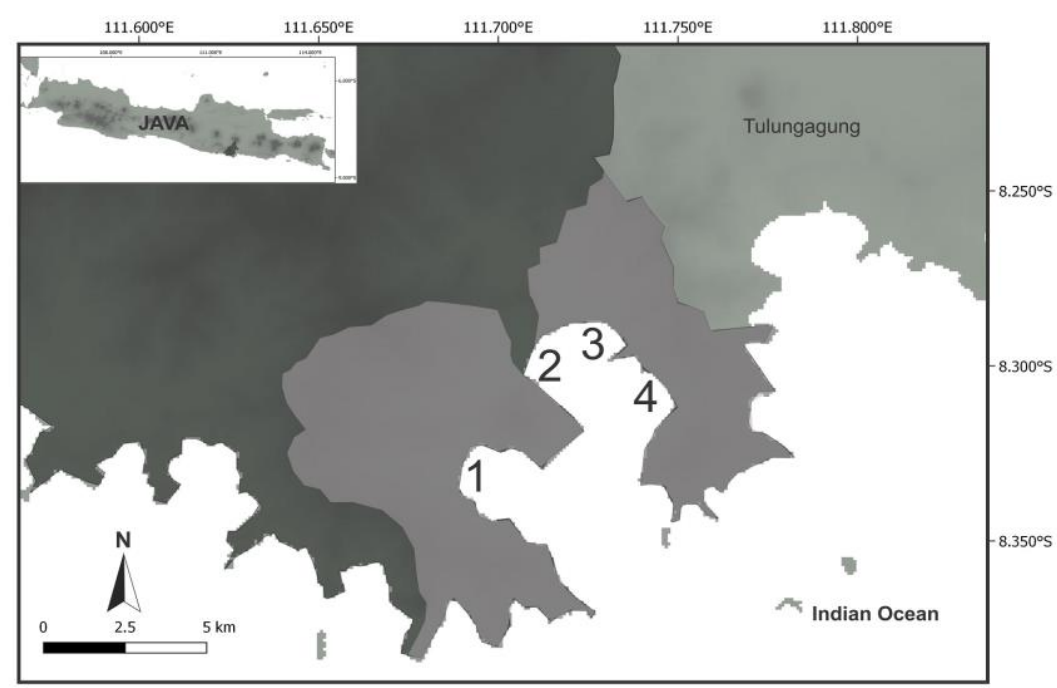

Figure 1. Study Sites. Description: Damas (1); Cengkrong (2); Prigi (3); Karanggongso (4); dark grey (Trenggalek Regency); grey (study sites); light grey (other regency) 
Analysis of internal and external strategy factors is done through rating on each strategic factor. Strategic factors are the dominant factors of strengths, weaknesses, opportunities, and threats that affect the existing conditions and situations and provide benefits when positive action is taken. The number of weight on each environments when summed should be $=1$ (one), with scale 1.0 (very important) up to 0.0 (not important). For rating value based on the magnitude of the influence of strategic factors on his condition with the provision of scale ranging from 4 (very strong) to 1 (weak). Positive variables (strength or opportunity variables) are rated from 1 to 4 by comparing with the average main competitor. While variables are negative opposite, if the weakness or big threat (compared with the average of similar competitors) is 1 , whereas if the value of the threat is small/below the average of its competitors is 4 .

\section{RESULT AND DISCUSSION Internal Factors}

Most respondents believe that promotion (0.083) and tourist information center (0.075) indicator (Table 1) are considered very important given that the existing marine tourism attraction in Watulimo is currently less known. It is necessary to have a comprehensive promotion and supported by the tourist information center as a pointer of information about the presence of marine tourism sites in Watulimo.

Other districts have achieved high revenues, some of which are from marine tourism. Banyuwangi is one example of a district in East Java that has managed to get great benefits from marine tourism. In 2013 alone, visits in Banyuwangi have increased significantly, namely foreign tourists $(5,502$ to 10,462 people or $90 \%)$ and domestic tourists $(860,831$ to $1,057,952$ people or 24\%). The growth of Banyuwangi tourism is due to the intense promotion of tourism by local government from 2012-2013 [9]. Local government support, as in Banyuwangi, can strengthen the development of marine tourism in Watulimo.

The natural beauty indicator is the third indicator (0.073) and is considered important. Most respondents argued that the natural beauty indicator is the most important indicator because this indicator can reflect the natural beauty of marine tourism in Watulimo as a tourist attraction. The natural beauty of marine tourism in Trenggalek Regency has been proven by the presence of tourists both local and foreign [4]

Table 1. Weighting Internal Factors of Marine Tourism in Trenggalek Regency

\begin{tabular}{lc}
\hline \multicolumn{1}{c}{ Variable/Indicator } & Weight \\
\hline Attraction & \\
Beauty of nature & 0.073 \\
Cleanliness of environment & 0.068 \\
\hline Accessibility & \\
Distance from Trenggalek Regency Capital & 0.061 \\
Quality of roads & 0.072 \\
Availability of tourist transport & 0.062 \\
\hline Amenities & \\
Tourist attraction & 0.060 \\
Toilet & 0.062 \\
Parking lot & 0.062 \\
Stalls and street vendors & 0.062 \\
Praying spot & 0.065 \\
\hline Ancillary service & \\
Attraction manager & 0.068 \\
Service quality & 0.063 \\
Promotion & 0.083 \\
Tourist Information Center & 0.075 \\
Regulations & 0.064 \\
\hline
\end{tabular}

Indicator of tourism facilities in the existing marine tourism area in Watulimo get the lowest weight of 0.060 . A small percentage of respondents argue that this indicator can be an attraction for tourists in determining where to stay and in terms of services. On the contrary, most believe that enjoying marine tourism in Watulimo requires no tourism facilities and can immediately provide satisfaction for visitors. Indicator of marine tourism attraction close to the capital of Trenggalek Regency is the second weakness factor (0.061), where for the respondent a considerable distance does not make it easy for the visitors to access and enjoy the tourist attraction directly.

Most respondents argue that the first very good value indicator is natural beauty with a value of 3.65 (Table 2). According to the respondents, Wisata Bahari Trenggalek Regency has the power of natural beauty such as beach with white sand, beauty of coral reefs and clear sea water. The second indicator that get very good value and become the strength in the development of maritime tourism attraction in Trenggalek regency is the quality of the road to the tourist attractions, which has a large value of 3.17. Most respondents argue that the quality of marine area roads in District Watulimo Trenggalek Regency has been very good since the existence of the Jalur Lintas Selatan (South Roadway) project linking the southern beaches in East Java Province. 
Indicator which is the weakness in tourism development is tourist information center with value $\mathbf{1 . 9 6}$ and second threat that is manager of tourism facility at maritime area of Trenggalek Regency, 2.10. Most respondents argue that the tourist information center indicator that is not yet available and the indicators of tourism attraction managers are considered less because the public and the government has not been synergistic in the planning of tourism development of marine tourism area. This area is also still very lacking in tourism facilities. The means in question are hotels, inns, cafes, and other tourism support facilities. This is evidenced not only by the opinions of respondents but also by direct observation by researchers in the field. However, if viewed from the point of view of convenience then the tourists who visit can be more relaxed if they find adequate tourism facilities.

Table 2. Rating of Internal Factors of Marine Tourism

\begin{tabular}{lcc}
\multicolumn{1}{c}{ in Trenggalek Regency } & & \\
\hline \multicolumn{1}{c}{ Variable/Indicator } & Rating & Description \\
\hline Attraction & & \\
Beauty of nature & 3.65 & Strength \\
Cleanliness of environment & 2.96 & Strength \\
\hline Accessibility & & \\
Distance from Trenggalek & & \\
regency capital & 2.73 & Strength \\
Quality of roads & 3.17 & Strength \\
Availability of tourist transport & 3.05 & Strength \\
\hline Amenities & & \\
Tourist attraction & 2.10 & Weakness \\
Toilet & 2.35 & Weakness \\
Parking lot & 2.53 & Strength \\
Stalls and street vendors & 2.35 & Weakness \\
Praying spot & 2.50 & Weakness \\
\hline Ancillary service & & \\
Attraction manager & 2.10 & Weakness \\
Service quality & 2.17 & Weakness \\
Promotion & 2.51 & Strength \\
Tourist Information Center & 1.96 & Weakness \\
Regulations & 2.60 & Strength \\
\hline
\end{tabular}

\section{External Factors}

Advances in information technology have the highest weight (0.097), where respondents can know about the state of the marine tourism area based on information and reviews. Information is very important for travelers, such as information of access, conditions, and other purposes in enjoying a tourist attraction (Table 3). Advances in information such as the internet and telephone networks can make it easier for travelers to visit, and place orders without having to come directly [10]. This indicator is considered very important in the development of marine tourism area in Trenggalek regency.

Table 3. Weighting of External Factors on Marine Tourism

\begin{tabular}{lc}
\multicolumn{1}{c}{ Area } & Weight \\
\hline \multicolumn{1}{c}{ Variable/Indicator } & \\
\hline Environment & 0.092 \\
Public awareness in preserving environment & 0.054 \\
Global Warming & \\
\hline Economy & 0.074 \\
National economic conditions & 0.081 \\
Global economic conditions & \\
\hline Socio-culture & 0.097 \\
Community participation in preserving culture & \\
\hline Advance in Technology & 0.092 \\
Transportation & 0.097 \\
Information & \\
\hline Politics and Government & 0.070 \\
Global political conditions & 0.075 \\
National political conditions & 0.087 \\
Government policy in tourism development & 0.095 \\
\hline Security of marine tourism area in Trenggalek & \\
\hline Competitiveness & \\
Competitiveness with similar tourist & 0.086 \\
\hline attraction & $\mathbf{1}$ \\
\hline Total &
\end{tabular}

Notes: Weighting of external factors is done on a scale of 0.0 (unimportant) to 1.0 (very important), where the total of all weights must be equal to 1 .

Security of marine tourism area is the second most important indicator (0.095), as shown in Table 3. This indicator is considered the most important considering the safety conditions of marine tourism areas to be one reason for tourist visits. Security is able to provide a sense of comfort for tourists in doing tourism activities and facilitate managers in doing promotion [11].Global warming gained the lowest weight (0.054), and most respondents thought that this indicator was less important. Nevertheless, with the issue of global warming in the hope that the government and society to maintain and pay attention to the sustainability of the environment so that it can be passed on to future generations.

Global warming has had a devastating impact on tourism, especially with regard to animal behavior, growing, as well as growing of flowering plants, as well as the destruction of natural landscape and liming of coral $[11,12,13]$. Based on that, Trenggalek regency government and marine tourism community should be wary of investor behavior that is not environmentally friendly and tend to utilize excessive natural resources to gain profit which can damage marine tourism environment. This is because the maritime region and all marine biota in it, is the front row of environmental impacts of global warming. 
Most argue that the safety of marine tourism areas has the highest probability (3.5; Table 4). This shows that the condition of marine tourism security in Trenggalek regency in general is still good and under control, because it is supported by good cooperation between police and society. In addition, there are rules and customary managers who support the security of tourist areas. Tourists in a visit to a tourist destination require a sense of security and comfort so that it can extend the stay (lengths of stay) and the presence of repeat visits (repeater guest) [14].

Table 4. Result of External Factor Assessment of Marine Tourism Area in Trenggalek Regency

\begin{tabular}{|c|c|c|}
\hline Variable/Indicator & Rating & Description \\
\hline \multicolumn{3}{|l|}{ Environment } \\
\hline $\begin{array}{l}\text { Public awareness in preserving } \\
\text { the environment }\end{array}$ & 2.25 & Threat \\
\hline Global Warming & 1.36 & Threat \\
\hline \multicolumn{3}{|l|}{ Economy } \\
\hline National economic conditions & 2.89 & Opportunity \\
\hline Global economic conditions & 2.67 & Opportunity \\
\hline \multicolumn{3}{|l|}{ Socio-culture } \\
\hline $\begin{array}{l}\text { Community participation in } \\
\text { preserving culture }\end{array}$ & 2.98 & Opportunity \\
\hline \multicolumn{3}{|l|}{ Advance in Technology } \\
\hline Transportation & 2.60 & Opportunity \\
\hline Information & 2.03 & Threat \\
\hline \multicolumn{3}{|l|}{ Politics and Government } \\
\hline Global political conditions & 2.89 & Opportunity \\
\hline National political conditions & 2.87 & Opportunity \\
\hline $\begin{array}{l}\text { Government policy in tourism } \\
\text { development }\end{array}$ & 2.59 & Opportunity \\
\hline $\begin{array}{l}\text { Security of marine tourism area } \\
\text { in Trenggalek Regency }\end{array}$ & 3.5 & Opportunity \\
\hline \multicolumn{3}{|l|}{ Competitiveness } \\
\hline $\begin{array}{l}\text { Competitiveness with similar } \\
\text { tourist attraction }\end{array}$ & 2.85 & Opportunity \\
\hline
\end{tabular}

The indicator considered as the second opportunity is the participation of the community in preserving the culture (2.98). Recent tourist trends indicate a shift of tourist interest from conventional tourism to alternative tourism, which one of them is spiritual tourism [15]. The development of spiritual and historical tourism is in line with the increasing desire of people to seek silence and inner calm and out of the busy routine and pressures of life faced in the era of globalization.

The results show the number of scores obtained from the weighting and external factor rating of 2.656 (good value range) (table 5). This illustrates that the marine tourism area in Watulimo has a great opportunity in its development as a tourist attraction. However, some indicators point to some threats that need to be addressed for further development.

Table 5. Results of Assessment and Weighting of External Factors of Marine Tourism Area in Trenggalek Regency

\begin{tabular}{|c|c|c|c|}
\hline Variable/Indicator & Weight & Value & WxV \\
\hline \multicolumn{4}{|l|}{ Environment } \\
\hline $\begin{array}{l}\text { Public awareness in preserving } \\
\text { the environment }\end{array}$ & 0.092 & 2.25 & 0.207 \\
\hline Global Warming & 0.054 & 1.36 & 0.073 \\
\hline \multicolumn{4}{|l|}{ Economy } \\
\hline National economic conditions & 0.074 & 2.89 & 0.214 \\
\hline Global economic conditions & 0.081 & 2.67 & 0.216 \\
\hline \multicolumn{4}{|l|}{ Socio-culture } \\
\hline $\begin{array}{l}\text { Community participation in } \\
\text { preserving culture }\end{array}$ & 0.097 & 2.98 & 0.289 \\
\hline \multicolumn{4}{|l|}{ Advance in Technology } \\
\hline Transportation & 0.092 & 2.60 & 0.239 \\
\hline Information & 0.097 & 2.03 & 0.197 \\
\hline \multicolumn{4}{|l|}{ Politics and Government } \\
\hline Global political conditions & 0.070 & 2.89 & 0.202 \\
\hline National political conditions & 0.075 & 2.87 & 0.215 \\
\hline $\begin{array}{l}\text { Government policy in tourism } \\
\text { development }\end{array}$ & 0.087 & 2.59 & 0.225 \\
\hline $\begin{array}{l}\text { Security of marine tourism area } \\
\text { in Trenggalek Regency }\end{array}$ & 0.095 & 3.5 & 0.333 \\
\hline \multicolumn{4}{|l|}{ Competitiveness } \\
\hline $\begin{array}{l}\text { Competitiveness with similar } \\
\text { tourist attraction }\end{array}$ & 0.086 & 2.85 & 0.245 \\
\hline Total & 1 & & 2.656 \\
\hline
\end{tabular}

\section{Strategy}

From the matrix of Internal Factor analysis summary (IFAS) (Table 6), it can be seen that the total score of strength variable (1.582) is greater than the total score of weakness variable (1.008). This illustrates that the development of Watulimo marine tourism will not be disturbed by its internal weaknesses and is strongly supported by the potential power that it naturally has over the years.

Based on External Factor Analysis Summary (EFAS) matrix (Table 7), it is known that total score of opportunity variable (2.719) is greater than total score of threat variable (0.477). Thus, it can be said that in the development of marine tourism area of Trenggalek Regency, opportunity variable is more influential than the threat variables. This illustrates that the development of Watulimo marine tourism will not be disturbed by external threats, even some supporting factors can accelerate its development. Both IFAS and EFAS illustrate that Watulimo marine tourism still has great potential to continue to grow. IFAS and EFAS form the basis of subsequent development actions to minimize weaknesses (IFAS) and threats (EFAS), and enlarge future (IFAS) and opportunities (EFAS) strengths $[16,17]$. 
Table 6. IFAS Matrixof Marine Tourism Area in Trenggalek Regency

\begin{tabular}{lccc}
\hline Strength variable & Weight & Rating & Score \\
\hline Beauty of nature & 0.073 & 3.65 & 0.266 \\
Cleanliness of environment & 0.068 & 2.96 & 0.201 \\
Distance from TrenggalekRegency capital & 0.061 & 2.73 & 0.167 \\
Road quality & 0.072 & 3.17 & 0.228 \\
Availability of tourist transport & 0.062 & 3.05 & 0.189 \\
Parking lot & 0.062 & 2.53 & 0.157 \\
Promotion & 0.083 & 2.51 & 0.208 \\
Regulations & 0.064 & 2.60 & 0.166 \\
\hline & & & $\mathbf{1 . 5 8 2}$ \\
\hline Weakness variable & Weight & Rating & Score \\
\hline Tourist attraction & 0.060 & 2.10 & 0.126 \\
Toilet & 0.062 & 2.35 & 0.146 \\
Stalls and street vendors & 0.062 & 2.35 & 0.146 \\
Praying spot & 0.065 & 2.50 & 0.163 \\
Attraction manager & 0.068 & 2.10 & 0.143 \\
Service quality & 0.063 & 2.17 & 0.137 \\
Tourist Information Center & 0.075 & 2.60 & 0.166 \\
\hline & & & $\mathbf{1 . 0 0 8}$ \\
\hline Total & & & $\mathbf{2 . 5 9 0}$ \\
\hline
\end{tabular}

Table 7. EFAS Matrixof Marine Tourism Area in Trenggalek Regency

\begin{tabular}{lccc}
\hline Opportunity Variables & Weight & Rating & Score \\
\hline National Economic Conditions & 0.074 & 2.89 & 0.214 \\
Global Economic Conditions & 0.081 & 2.67 & 0.216 \\
Community participation in preserving culture & 0.097 & 2.98 & 0.289 \\
Transportation & 0.092 & 2.60 & 0.239 \\
Global Politics Conditions & 0.070 & 2.89 & 0.202 \\
National Politics Condition & 0.075 & 2.87 & 0.215 \\
Government policy in tourism development & 0.087 & 2.59 & 0.225 \\
Security of marine tourism area of Trenggalek Regency & 0.095 & 3.50 & 0.333 \\
Competitiveness with similar tourist attraction & 0.086 & 2.58 & 0.245 \\
\hline & & & $\mathbf{2 . 7 1 9}$ \\
Threat Variables & Weight & $\mathbf{R a t i n g}$ & $\mathbf{S c o r e}$ \\
\hline Public awareness in preserving the environment & 0.092 & 2.25 & 0.207 \\
Global Warming & 0.054 & 1.36 & 0.073 \\
Information & 0.097 & 2.03 & 0.197 \\
\hline & & & $\mathbf{0 . 4 7 7}$ \\
\hline Total & & & $\mathbf{2 . 6 5 6}$ \\
\hline
\end{tabular}

Strengths such as attractiveness, access and friendliness of the population can be utilized to seize the greatest opportunity so that the appropriate strategy is to increase promotion. Promotion is intended to expand market share and increase the number of visits to the marine tourism area of Watulimo. The function of promotion is to communicate all sorts of information about all that is owned, and can be offered to tourists. The program that needs to be done is to make brochures and pages on a continuous basis containing the attraction and facilities available in Watulimo. This kind of program could increase cooperation with tourism industry both domestic and foreign in terms of promotion and distribution of tourists.

As the challenges and assets possessed by the development of Watulimo marine tourism, promotion is an important part of an acceleration of tourism [9]. SWOT strategy analysis (Appendix 1) has demonstrated the need for adaptation of promotion through both conventional and current media, such as social media. Social media is part of the latest generation of information-based technologies with a wide range and low cost, and a great potential for ecotourism promotion [18]. Cooperation with travel agents, hotels, restaurants, and tourist information centers for Watulimo Beach development can be incorporated into their brochures to increase tourism traffic.

The selected strategy is as followsin SWOT matrix analysis (Appendix 1). Continuous promotion through local TV, radio and social media is aimed at: (1) expanding market share and 
increasing the number of visits to Watulimo marine tourism; (2) synergize and enhance cooperation with tourism industry actors at home and abroad, especially in terms of tourism promotion and tourist distribution; (3) synergize cooperation with travel agents, hotels, restaurants, and tourist information centers so that information about tourism in Watulimo can be incorporated into the information system. The importance of transportation sector in supporting tourism promotion [19]. Transport and promotion are also main factor in the development of tourist areas [20-24].

Unfortunately, little attention is given to the changing environment and the impact of global warming. Inevitably, the addition of visits to a tourist attraction will have an impact on the environment and its sustainability as a tourist site [25]. The SWOT strategy shows several strategies in anticipating this: Conducting and maintaining environmental sustainability, Involving community in tourism development, establish a governing body, and increasing human resources in tourism (detail in Appendix 1).

\section{CONCLUSION}

The development of marine tourism area of Trenggalek Regency is influenced by internal factors (promotion and tourist information center) and external factors (information technology). The development of the Watulimo marine tourism area as a sustainable form of tourism requires several strategies: 1 ) increasing promotion; 2) to arrange and preserve the environment and involve the community in tourism development; 3) develop more varied tourist attraction products and develop tourism facilities, and public facilities; and 4) establishing a governing body and improving human resources.

\section{REFERENCES}

[1] Public Relation Trenggalek. 2015. Peringatan Hari Nusantara XIII Provinsi Jawa Timur di Pelabuhan Perikanan Nusantara (PPN). Available at: http://humassetda.trenggalek kab.go.id.

[2] Dahuri, R., J. Rais, S. P. Ginting, and M. J. Sitepu. 2001. Pengelolaan sumberdaya wilayah pesisir dan lautan secara terpadu. Pradnya Paramita. Bogor.

[3] Faizal, M. I., L. Hakim, and N. Harahap. 2017. Factors affecting level of participation in the management of mangroves as ecotourism attraction: lesson learned from Cengkrong Watulimo, Trenggalek. Journal of Indonesian Tourism and Development Studies 5(1), 19-24.

[4] Office for Tourism, Youth and Sport, Trenggalek. 2016. Data jumlah kunjungan wisatawan. Trenggalek Regency. Available at: http://www.trenggalekkab.go.id.

[5] Cameron, C. M., and J. B. Gatewood. 2008. Beyondsun, sand, and sea: the emergent tourism program in the Turks and Caicos Island. Journal of Heritage Tourism 3(1), 5573.

[6] Kundur, S. K. 2012. Development of tourism in Maldives. International Journal of Scientific and Research Publications 2(4), 1-5.

[7] Bunghez, C. L. 2016. The importance of tourism to a destination's economy. Journal of Eastern Europe Research in Business and Economics. Article ID 143495.

[8] Hakim, L., M. Soemarno, and S. K. Hong. 2012. Challenges for conserving biodiversity and developing sustainable island tourism in North Sulawesi Province, Indonesia. Journal of Ecology and Environment 35(2), 61-71.

[9] Avinda, C. B., I. N. Sudirta, and N. M. O. Karini. 2016. Strategi promosi Banyuwangi sebagai destinasi wisata (studi kasus pada Dinas Kebudayaan dan Pariwisata). Jurnal Industri Perjalanan Wisata 4(1), 55-60.

[10] Stange, J., D. Brown, and S. International. 2007. Tourism destination management: achieving sustainable and competitive results. Online tool kit and resource series, USAID. Available at: www.usaid.gov.

[11] Amedie, F. A. 2013. Impacts of climate change on plant growth, ecosystem services, biodiversity, and potential adaptation measures. Master Thesis. Atmospheric Science Program. Interest: Environmental Science. University of Gothenberg. Sweden.

[12] Fuentes, M. M. P. B., M. Hamann, and C. J. Limpus. 2010. Past, current and future thermal profiles of green turtle nesting grounds: implications from climate change. Journal of Experimental Marine Biology and Ecology 383, 56-64.

[13] Done, T., P. Whetton, R. Jones, R. Berkelmans, J. Lough, W. Skirving, and S. Wooldridge. 2003. Global climate change and coral bleaching on the Great Barrier Reef. Department of Natural Resources and Mines. Queensland.

[14] WTO. 1996. Tourist safety and security: practical measures for destinations. World Tourism Organization. Madrid. 
[15] Norman, A. 2011. Spiritual tourism: travel and religious practice in Western Society. Bloomsbury Publishing PLC. United Kingdom.

[16] Andrades, L., and F. Dimanche. 2017. Destination competitiveness and tourism development in Russia: issues and challenges. Tourism Management 62, 360376.

[17] Boukas, N., and V. Ziakas. 2016. Tourism policy and residents' well-being in Cyprus: opportunities and challenges for developing an inside-out destination management approach. Journal of Destination Marketing and Management 5(1), 44-54.

[18] Zeng, B. 2013. Social media in tourism. Journal of Tourism and Hospitality 2(1), $1000 \mathrm{e} 125$.

[19] Truong, N. V., and T. Shimizu. 2017. The effect of transportation on tourism promotion: literature review on application of the Computable General Equilibrium (CGE) model. Transportation Research Procedia 25, 3096-3115.

[20] Dudensing, R. M., D. W. Hughes, and M. Shields. 2011. Perceptions of tourism promotion and business challenges: A survey-based comparison of tourism businesses and promotion organizations. Tourism Management 32(6), 1453-1462.

[21] Gabor, M. R., and L. C. Contiu. 2012. Measuring the impact of promotion campaigns intended to educate tourism services consumers from Romania using Kelly's theory. Procedia: Social and Behavioral Sciences 46, 5558-5562.

[22] Hui-Shi. 2012. The efficiency of government promote of inbound tourism: the case of Australia. Economic Modelling 29(6), 27112718.

[23] Bajada, T., and H. Titheridge. 2017. The attitudes of tourists towards a bus service: implications for policy from a Maltese case study. Transportation Research Procedia 25, 4110-4129.

[24] Liao, Z., and X. Shi. 2017. Web functionality, web content, information security, and online tourism service continuance. Journal of Retailing and Consumer Service 39, 258263.

[25] Neto, F. 2003. A new approach to sustainable tourism development: moving beyond environmental protection. DESA Discussion paper no.29. Department of
Economic and Social Affairs, United Nations. New York. 
Appendix 1.SWOT matrix analysis

\begin{tabular}{|c|c|c|}
\hline $\begin{array}{l}\text { Extern Factor } \\
\text { (EFAS) }\end{array}$ & $\begin{array}{l}\text { STRENGTH (S) } \\
\text { 1. The beauty of nature } \\
\text { 2. Cleanliness and environmental } \\
\text { sustainability } \\
\text { 3. Distance with the capital of } \\
\text { Trenggalek Regency } \\
\text { 4. Quality of the road } \\
\text { 5. Availability of tourist transport } \\
\text { 6. Parking lot } \\
\text { 7. Promotion } \\
\text { 8. Regulations }\end{array}$ & \begin{tabular}{ll} 
& \multicolumn{1}{c}{ WEAKNESSES (W) } \\
1. & Tourism facilities \\
2. & Toilet \\
3. Stalls and street vendors \\
4. \\
5. The attraction manager \\
6. \\
7. & Touality of service \\
&
\end{tabular} \\
\hline $\begin{array}{l}\text { OPPORTUNITIES (O) } \\
\text { 1.National economic } \\
\text { conditions } \\
\text { 2.Global economic conditions } \\
\text { 3.Community participation in } \\
\text { preserving culture } \\
\text { 4. Transportation } \\
\text { 5.Global political conditions } \\
\text { 6.National political conditions } \\
\text { 7.Government policy in } \\
\text { tourism development. } \\
\text { 8.Safety of marine tourism } \\
\text { area in Trenggalek } \\
\text { Regency. } \\
\text { 9.Competitiveness with } \\
\text { similiar tourist attraction. }\end{array}$ & $\begin{array}{l}\text { STRATEGY SO } \\
\text { 1. Promotion is done continuously either } \\
\text { using print media, TV, radio and social } \\
\text { media to expand market share and } \\
\text { increase the number of visits to } \\
\text { marine tourism area in Trenggalek } \\
\text { Regency. } \\
\text { 2. Increased cooperation with the tourism } \\
\text { industry either domestically or abroad } \\
\text { in terms of promotion and distribution } \\
\text { of tourists. } \\
\text { 3. Cooperation with travel agents, hotels, } \\
\text { restaurants, and tourist information } \\
\text { centers for Trenggalek Regency can } \\
\text { be incorporated into their brochures to } \\
\text { increase traffic. }\end{array}$ & $\begin{array}{l}\text { STRATEGY WO } \\
\text { 1. Developing more varied tourist } \\
\text { attraction products. Tourist } \\
\text { attraction is one element that can } \\
\text { attract tourists to visit. Trenggalek } \\
\text { Regency marine tourism attraction } \\
\text { consists of beautiful nature, } \\
\text { especially the scenery of cliffs, } \\
\text { coastline, and underwater scenery } \\
\text { 2onservation activities as an } \\
\text { attraction, such as a turtle breeding } \\
\text { ground } \\
\text { Mapping the potential of marine } \\
\text { tourism in Trenggalek Regency for } \\
\text { diving, snorkeling and trekking } \\
\text { activities but also can be } \\
\text { developed other types of tourism } \\
\text { are: spiritual tourism, cultural } \\
\text { tourism by displaying cultural arts } \\
\text { performances are owned regularly } \\
\text { to tourists, educational tours by } \\
\text { inviting students to visit the } \\
\text { breeding grounds and learn about } \\
\text { turtles. } \\
\text { Development of tourism facilities is } \\
\text { needed in the marine tourism area } \\
\text { to meet all the needs of tourists } \\
\text { during a visit. In addition to } \\
\text { providing comfort for tourists. Can } \\
\text { also affect the length of stay and } \\
\text { the average expenditure per day of } \\
\text { tourists, thus increasing the income } \\
\text { of the community. } \\
\text { The presence of tourist information } \\
\text { center in strategic locations could } \\
\text { assist and guide the tourist in } \\
\text { marine tourism area } \\
\text { Develop public facilities by } \\
\text { repairing roads, structuring the bus } \\
\text { terminal, and providing lighting in } \\
\text { the streets at night. The provision } \\
\text { of adequate public facilities affects } \\
\text { the convenience of travelers in } \\
\text { traveling, and is also beneficial to } \\
\text { the local community. }\end{array}$ \\
\hline
\end{tabular}




\begin{tabular}{|c|c|c|}
\hline $\begin{array}{l}\text { Extern Factor } \\
\text { (EFAS) }\end{array}$ & $\begin{array}{l}\text { STRENGTH (S) } \\
\text { 1. The beauty of nature } \\
\text { 2. Cleanliness and environmental } \\
\text { sustainability } \\
\text { 3. Distance with the capital of } \\
\text { Trenggalek Regency } \\
\text { 4. Quality of the road } \\
\text { 5. Availability of tourist transport } \\
\text { 6. Parking lot } \\
\text { 7. Promotion } \\
\text { 8. Regulations }\end{array}$ & \begin{tabular}{ll} 
& \multicolumn{1}{c}{ WEAKNESSES (W) } \\
1. & Tourism facilities \\
2. & Toilet \\
3. & Stalls and street vendors \\
4. & Mushola (praying room) \\
5. & The attraction manager \\
6. & Quality of service \\
7. & Tourist Information Center
\end{tabular} \\
\hline $\begin{array}{l}\text { THREATS }(\mathbf{T}) \\
\text { 1. Public awareness in } \\
\text { preserving the } \\
\text { environment } \\
\text { 2. Global warming } \\
\text { 3. Information }\end{array}$ & $\begin{array}{l}\text { STRATEGYST } \\
\text { 1. Conducting and maintaining } \\
\text { environmental sustainability. } \\
\text { Maritime tourism Trenggalek } \\
\text { Regency has a genuine environment } \\
\text { and less maintained, so it needs to } \\
\text { be done such as setting up a park in } \\
\text { the places of marine tourism } \\
\text { 2. Involving community in tourism } \\
\text { development. In the development of } \\
\text { a sustainable tourism area the main } \\
\text { key is the involvement of the } \\
\text { community, from the time of } \\
\text { planning, management and } \\
\text { supervision } \\
\text { Conservation efforts on the potential } \\
\text { of art and culture that is used as an } \\
\text { attraction by establishing dance } \\
\text { groups and improve the creativity of } \\
\text { the community. }\end{array}$ & $\begin{array}{l}\text { STRATEGY WT } \\
\text { Establish a governing body. A } \\
\text { tourism area will be managed } \\
\text { properly if it has a special } \\
\text { management agency that has the } \\
\text { function and authority to manage } \\
\text { the area. The body includes } \\
\text { elements of society, government, } \\
\text { practitioners and NGOs that will } \\
\text { affect the satisfaction and comfort } \\
\text { of tourists. The existence of the } \\
\text { governing body can minimize the } \\
\text { threat to the marine tourism area } \\
\text { of Trenggalek Regency. The } \\
\text { activities of this body include } \\
\text { promotions. } \\
\text { Increasing Human Resources in } \\
\text { tourism. The tourism industry's } \\
\text { dominant product is services, for } \\
\text { which human labor is necessary. } \\
\text { Tourists will feel satisfied if served } \\
\text { well, so it takes a professional } \\
\text { workforce in the field of tourism } \\
\text { and able to compete. }\end{array}$ \\
\hline
\end{tabular}

